\title{
Morphological variation in two sigmodontine rodents along the mainland and the Fuegian archipelago in Chilean southern Patagonia
}

Alejandro Valladares-Gómez ${ }^{1 *+}$, Marcela Huenumilla-Linares ${ }^{1}$, Enrique Rodríguez-Serrano ${ }^{2}$, Cristián E. Hernández ${ }^{3,4}$ and R. Eduardo Palma ${ }^{1+}$

\begin{abstract}
Background: Analysis of morphological variation in archipelagos has been essential to understand the evolution of terrestrial vertebrates. In particular, these natural scenarios allow to assess morphological changes experienced by insular fauna compared to their mainland counterparts. In mammals, morphological changes of insular forms have been observed in size and shape of body and cranial traits. The southern Patagonia of Chile represents a unique scenario to analyze morphological variation in two of the most widely distributed small rodents along western southern South America: Abrothrix olivacea and Oligoryzomys longicaudatus.
\end{abstract}

Methods: We applied linear and three-dimensional geometric morphometric tools to analyze the variation in cranial morphology of A. olivacea $(N=80)$ and O. longicaudatus $(N=49)$. Sampled localities were distributed in the mainland and islands of the Fuegian archipelago in Chilean Patagonia. Standard multivariate methods, as Principal Components Analysis, and Logistic Regression models were carried out to evaluate differences in size and shape of crania.

Results: We detected higher levels of morphological variation in the crania of A. olivacea if compared to $O$. longicaudatus. The variation was associated to cranial size instead of shape.

We observed significant differences between insular and mainland individuals in A. olivacea, being the cranium size of this species significantly bigger on islands. Indeed, specimens of A. olivacea from "Isla Wellington", exhibited the higher increment in cranium size compared to any other mainland and insular site sampled for this species. In contrast, insular and mainland forms of $O$. longicaudatus did not show significant differences in cranial morphology.

Conclusions: We suggest that the patterns of morphological variation observed in these two small rodents along Patagonia, could be explained in terms of the historical biogeography of the region, and the different ecological features of the studied species.

Keywords: Abrothrix olivacea, Geometric morphometrics, Linear morphometrics, Oligoryzomys longicaudatus

\footnotetext{
* Correspondence: avalladares@bio.puc.cl

${ }^{\dagger}$ Alejandro Valladares-Gómez and R. Eduardo Palma contributed equally to this work.

'Laboratorio de Biología Evolutiva, Departamento de Ecología, Facultad de Ciencias Biológicas, Pontificia Universidad Católica de Chile, Av. Libertador Bernardo O'Higgins 340, 6513677 Santiago, Chile

Full list of author information is available at the end of the article
}

(c) The Author(s). 2020 Open Access This article is licensed under a Creative Commons Attribution 4.0 International License, which permits use, sharing, adaptation, distribution and reproduction in any medium or format, as long as you give appropriate credit to the original author(s) and the source, provide a link to the Creative Commons licence, and indicate if changes were made. The images or other third party material in this article are included in the article's Creative Commons licence, unless indicated otherwise in a credit line to the material. If material is not included in the article's Creative Commons licence and your intended use is not permitted by statutory regulation or exceeds the permitted use, you will need to obtain permission directly from the copyright holder. To view a copy of this licence, visit http://creativecommons.org/licenses/by/4.0/. 


\section{Background}

Analysis of morphological variation in archipelagos has been essential to understand the evolution of terrestrial vertebrates [1]. These natural scenarios allow to assess morphological changes experienced by insular fauna compared to their mainland counterparts [2, 3]. Commonly, insular faunas are considered "disharmonic" since much of the mainland fauna is absent. Hence, insular forms often develop adaptations to new conditions (new ecological niches), due to the absence of competitors and predators, thus a "relaxing" of some selective constraints that were present on the mainland $[4,5]$. For example, insular mammals tend to display morphological differences in body size, as well as skeleton, dental and cranial features in comparison to their mainland conspecifics $[6,7]$. There are examples where large mammals evolved into miniature forms on islands, whereas small continental mammals (mice for example) evolved into large insular forms. This phenomenon has been called the "Island Rule" [8-11]. Indeed, Foster [9] showed that predominantly rodents (if compared to marsupials, insectivores, lagomorphs and other mammals) tended to be larger on islands than on the mainland $[8,9]$, and that body sizes increased with the area of the island [12-14]. Also, further studies have demonstrated that size tend to increase with island isolation (the farther the island, the bigger the size) for six species of North American small mammals $[15,16]$. However, not only size change is involved, but shape is also another important component of the insular morphological variation [17]. For example, hypsodonty in herbivores and changes on the teeth shape have been observed on insular mice $[6,18]$. In the mouse opossum microbiotheriid marsupial Dromiciops gliroides a skull shape variation has been observed in the rostrum, being more compressed in the Chiloe Island than in the continental area of Chile [19]. According to the latter authors, this fact could be attributable to a different diet in the island with respect to the continent.

In southern Chile, a rise in the sea level following the Last Glacial Maximum (LGM) fragmented the southern Patagonian region, thus generating the fjords and the Fuegian archipelago [20, 21]. The geomorphology of the Chilean coast from 44 to $56^{\circ} \mathrm{S}$, which is characterized by fjords and small islands, represents a direct inheritance of last glaciation events [21]. About 20,000 years ago, most of the Andean cordillera between 44 to $56^{\circ} \mathrm{S}$ was covered by ice reaching the Pacific Ocean flank. The sea invaded the resultant topography of the deep glacial erosion as soon as the ice receded towards the end of the glaciation period about 13,000 years [21]. In this way, an entangled geomorphology characterized by a "network" of fjords and several small and medium sized islands was originated. Hence, the geological composition of the southern Patagonian of Chile is deeply linked to the
Fuegian archipelago because their separation from the continent by the Magellan Strait, and many other marine channels and fjords [20, 22].

In Chilean southern Patagonia, there are very few phylogenetic/phylogeographic studies that show the differentiation processes along Fuegian archipelago and the continent. Rodríguez-Serrano et al. [23] when analyzing samples from Wellington Island $\left(47^{\circ}-50^{\circ} \mathrm{S}\right)$ and the continental Southern Ice Fields (same latitude), proposed that the sigmodontine rodent Akodon markhami (Pine, 1973), a supposed endemic taxon to Patagonia, was an island subspecies of Abrothrix olivacea. This study, based on mitochondrial DNA sequences (Cytochrome $b$ and d-loop sequences), concluded that markhami was a member of the Abrotrichini as a geographic race. On the other hand, Belmar-Lucero et al. [24] assessed the phylogeography of the long-tailed sigmodontine mouse Oligoryzomys longicaudatus magellanicus from Patagonian islands such as Navarino, Tierra del Fuego and Riesco, located between 52 and $54^{\circ} \mathrm{S}$. These authors found no differences when comparing genetic data (i.e., karyotypes and mtDNA sequences) between the former islands and continental populations of southern Patagonia (i.e., Magallanes National Reserve, Fuerte Bulnes, Puerto de Hambre). Further, the latter findings were corroborated in an additional phylogeographic study that considered the complete distributional range of $O$. longicaudatus including Patagonian islands [25].

Lessa et al. [26] when comparing the phylogeographic pattern of 14 sigmodontine species within the PatagonianFuegian (Tierra del Fuego) region, found phylogeographic breaks in only four species (Euneomys chinchilloides, Abrothrix hirta, Geoxus valdivianus and Abrothrix olivacea). Interestingly, only $A$. olivacea, showed a break between mainland Patagonia and Tierra del Fuego island [26]. These authors suggested that the separation of $A$. olivacea clades may be explained by the geographic barrier of the Magellan Strait, whereas the other species showed phylogeographic breaks within the continent. On the other hand, Palma and Rodríguez-Serrano [27] described a new species of Oligoryzomys in Harrison and Capitán Aracena islands (56 S), located $150 \mathrm{~km}$ south of Punta Arenas, southern Patagonia of Chile, across Cabo Froward. This proposition was based on chromosome, morphology and a mtDNA phylogeny that clearly differentiated these insular specimens compared to mainland populations of $O$. longicaudatus. The new form has a $2 n=54$ chromosomes instead of $2 n=56$ of the mainland forms, and it is the sister species to O. longicaudatus in a mitochondrial based phylogeny. The diversification of the new form may represent a peripheral isolate of O. longicaudatus, that differentiated in isolation due to the erosive effect of Pleistocene glaciers, particularly during LGM [20, 22]. 
The former antecedents suggest the southern Patagonia of Chile as a highly dynamic biogeographic scenario. In this ecoregion inhabits two of the most widely distributed small sigmodontine rodents along the west of southern South America: Oligoryzomys longicaudatus and Abrothrix olivacea. The long-tailed mouse O. longicaudatus is distributed from about $27^{\circ} \mathrm{S}$ (Atacama region) southward to Patagonia. In that range, only three geographic races or subspecies are recognized [25]. This rodent characterizes by having a high vagility and home range that fluctuates between 320 to $4800 \mathrm{~m}^{2}$ (data for the Temperate Forests [28]). The other species, Abrothrix olivacea, the olive field mouse, has also an extense geographic distribution, encompassing from southern Perú southward to the Patagonia of Chile and Argentina. However, in that range at least seven geographic races are recognized of this rodent [29]. The higher geographic structure of $A$. olivacea would be consequence of its lower vagility and home range (730 to $2530 \mathrm{~m}$ [30]) when compared with O. longicaudatus. Despite both species are co-distributed along most of their geographic ranges, they use different habitat types; $O$. longicaudatus inhabit mostly in forest and bushy areas, whereas A. olivacea is found across bushy and grassland environments [28].

In the Patagonia, A. olivacea and O. longicaudatus are widely distributed on islands of different size of the Magallanic region, and in the mainland of southern Patagonia of Argentina and Chile [23, 25]. Island distance from the continent could be an important component to consider, since most of the islands in the Fuegian archipelago are very close to the continent (i.e., $3.7 \mathrm{~km}$ between the closest portion between Tierra del Fuego island and the continent). On the other hand, island size is another relevant feature of this landscape. For example, Tierra del Fuego is the biggest island of the Fuegian archipelago with $48,000 \mathrm{~km}^{2}$, whereas Isla Riesco, in the same archipelago, has an area of 5000 $\mathrm{km}^{2}$. Thus, the particular geomorphology of southern Patagonia of Chile, represents a unique scenario to assess the morphological differentiation of these two rodent species along the mainland and islands of the Fuegian archipelago.

The aim of this study was to analyze the cranial morphological variation of the sigmodontine rodents $A$. olivacea and $O$. longicaudatus in Chilean southern Patagonia. To achieve our goal, we used two independent morphometric approaches: linear and geometric morphometric (three-dimensional) methods. Because the differences in the vagility and adaptive local response of both species, we expect to find higher levels of morphological differentiation along the Patagonian range in A. olivacea with respect to O. longicaudatus. Additionally, we expect to find evidence of an eventual cranial size increment of insular individuals (the Island Rule) compared to mainland conspecifics, as it has been observed in other small rodents distributed in archipelagomainland systems [31].

\section{Methods}

\section{Study area and samples}

Study sites were located along southern Patagonia of Chile encompassing mainland and insular locations (Fig. 1). A total of 129 adult mice (i.e., with the molars fully erupted and variable tooth wear [32]), were analyzed in this study: A. olivacea $N=80$ and O. longicaudatus $N=49$ (Table 1). A total of 111 crania were evaluated by linear and three-dimensional geometric morphometric methods simultaneously. Other samples were analyzed by only one of these two approaches. For example, samples from Isla Capitán Aracena and Isla Navarino were assessed just by a geometric or a linear approach, respectively (See details in Additional file 1, Appendix A). Individuals were captured with Sherman traps placed over the ground and baited with oat and vanilla. Fieldwork protocols followed the standard bioethical and biosafety guidelines outlined by the American Society of Mammologists (ASM [33]), and the Centers for Disease Control and Prevention (CDC [34]), respectively. All of the new rodent captures were deposited at "Colección de Flora y Fauna Profesor Patricio Sánchez Reyes", (SSUC) Departamento de Ecología, Facultad de Ciencias Biológicas, Pontificia Universidad Católica de Chile. The captures were conducted under the Chilean Government authorization: Servicio Agrícola y Ganadero (SAG) and Corporación Nacional Forestal (CONAF), and the approval of the Bioethics Committee of Pontificia Universidad Católica de Chile. We also included three specimens of $O$. longicaudatus from Isla Navarino analyzed in the Collection of Mammals of the American Museum of Natural History (AMNH), New York, USA. Differences due to sexual dimorphism in the crania of $A$. olivacea and $O$. longicaudatus were discarded in our dataset after performing a Discriminant Function Analysis using MorphoJ v. 1.06d [35], based on geometric morphometric data (Discriminant function "Sex" Female/Male, see details in Additional file 1, Appendix B).

\section{Linear morphometric analysis}

A total of 124 crania were analyzed in the linear morphometric approach (A. olivacea $N=75 ;$ O. longicaudatus $N=49$ ). We registered 22 standard linear cranial measurements for each species with a digital caliper (0.01 $\pm \mathrm{mm}$ precision), following to Gallardo and Palma [36]: condylobasal length, basilar length, basal length, length of the diastema, length of the incisive foramen, palatal length, length of the maxillary tooth row, palatilar 


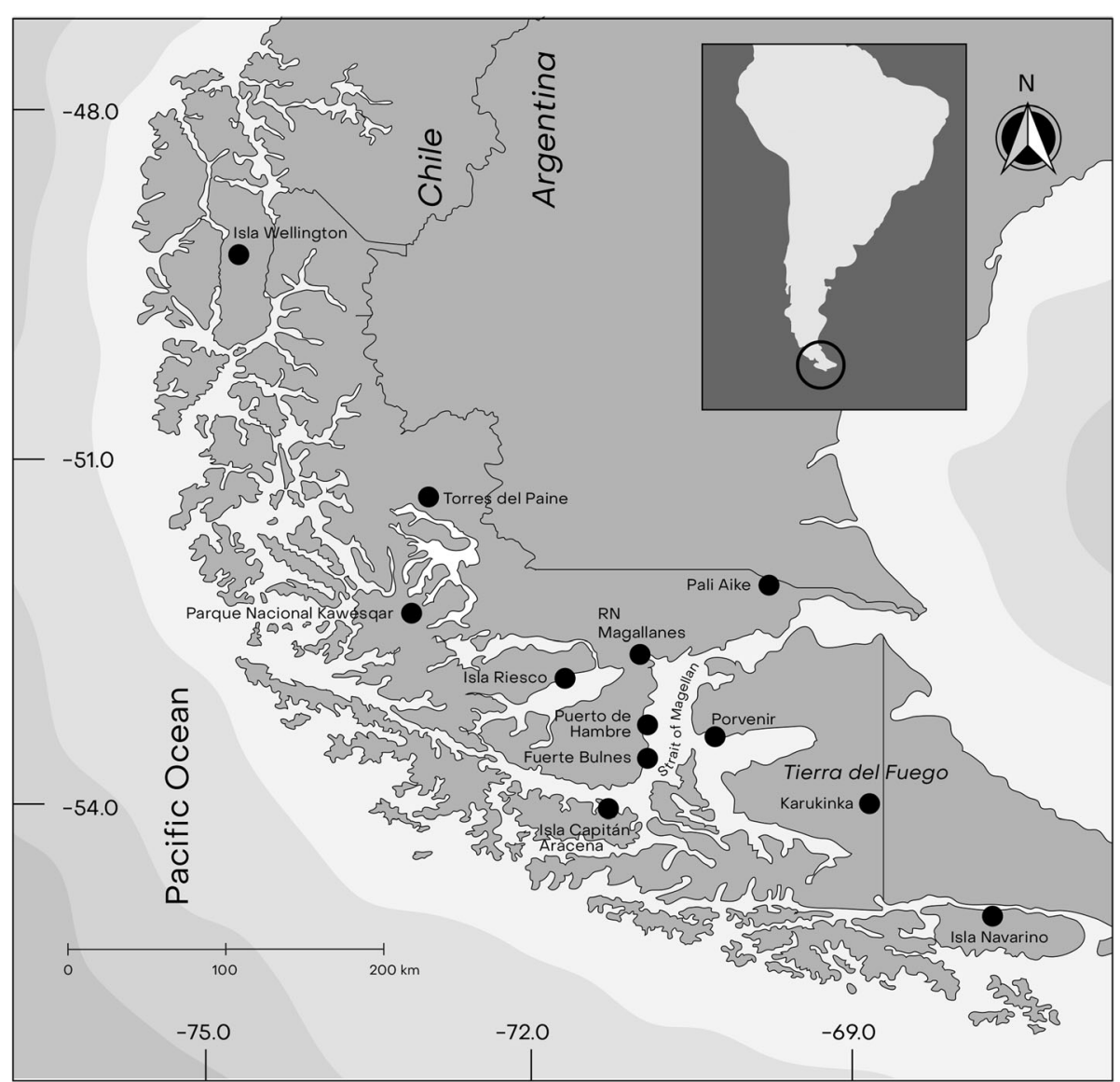

Fig. 1 Map of the study area including the mainland and islands of the southern Patagonia of Chile. PN = Parque Nacional, RN=Reserva Nacional

Table 1 Sample size and localities assessed in this study for A. olivacea and O. Iongicaudatus in the Chilean southern Patagonia. All localities are grouped by precedence, i.e., mainland or island

\begin{tabular}{|c|c|c|}
\hline & A. olivacea & O. longicaudatus \\
\hline Locality & Sample size & Sample size \\
\hline \multicolumn{3}{|l|}{ Mainland } \\
\hline RN Magallanes & - & 1 \\
\hline Puerto de Hambre & 6 & 2 \\
\hline Fuerte Bulnes & 6 & 11 \\
\hline PN Pali Aike & 16 & - \\
\hline PN Torres del Paine & 6 & 14 \\
\hline Total mainland & 34 & 28 \\
\hline \multicolumn{3}{|l|}{ Insular } \\
\hline Isla Wellington & 7 & 7 \\
\hline Isla Riesco & 12 & 6 \\
\hline PN Kawésqar & - & 2 \\
\hline Isla Capitán Aracena & 2 & - \\
\hline Porvenir (Isla Tierra del Fuego) & 13 & 2 \\
\hline Karukinka (Isla Tierra del Fuego) & 12 & 1 \\
\hline Isla Navarino & - & 3 \\
\hline Total insular & 46 & 21 \\
\hline Total sample size & 80 & 49 \\
\hline
\end{tabular}


length, postpalatal length, greatest length of skull, breadth of braincase, zygomatic breadth, mastoid breadth, condylonasal length, condylomolar length, palatal width, length of the tympanic bulla, width of the tympanic bulla, least interorbital breadth, nasal length, nasal width, and rostral breadth. Intraspecific morphological variation along insular and mainland samples of each species was analyzed by performing a Principal Component Analysis (PCA). Later, we used the first principal component (PC1) as a vector of the cranial size as suggested by Breno et al. [37] (details of eigenvalues and eigenvectors in Additional file 2), to test the probability that the bigger cranial sizes were associated to "island" (Category 1) or "mainland" localities (Category 0 ), performing a logistic regression model (LRM) implemented in the software Past 3.26 [38].

\section{Three-dimensional geometric morphometric analyses} Crania of A. olivaea $(N=73)$ and O. longicaudatus $(N=$ 43) were analyzed by geometric morphometric methods based on three-dimensional (3D) landmark coordinates. Due to landmark configuration contain size and shape information, both of these components can be assessed independently [39]. We built 3D models of crania using a Nextengine 3D laser scanner and the software Scantudio v.2.0.0 following Valladares-Gómez et al. [19]. A total of 21 landmarks were digitized on each cranium by the same observer (AV-G) in the software Landmark v.3.0 [40]. Each 3D model was digitized two times and an average landmark's configuration was obtained for a single cranium in MorphoJ v.1.06d [35]. The landmarks used in this study corresponded to a subset of the landmarks studied by Martínez et al. [32] for other sigmodontine rodents. See details of landmark's anatomical location and description in Fig. 2 and Table 2. We discarded the measurement error of digitization after the comparison of the two set of digitized landmarks by applying a Procrustes Analysis of Variance (Procrustes ANOVA), as it was described in Klingenberg et al. [41]
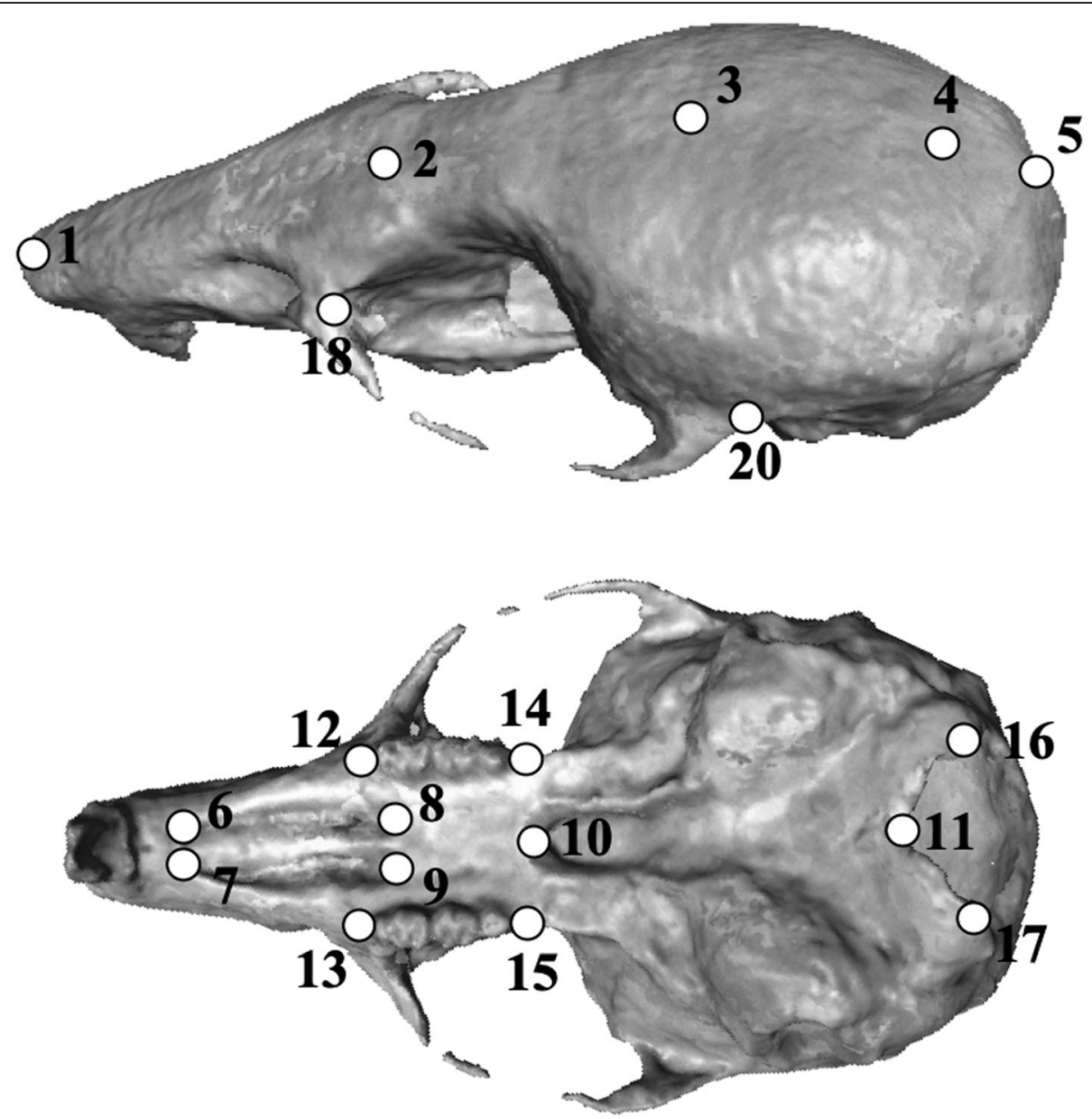

\section{$10 \mathrm{~mm}$}

Fig. 2 Anatomical location of the 21 landmarks used in this study for three-dimensional geometric morphometric analyses 
Table 2 Anatomical description of the landmarks used for three-dimensional geometric morphometric analyses. Anatomical description followed to Martínez et al. [32]

\begin{tabular}{ll}
\hline Landmark & Anatomical description \\
\hline 1 & Rostralmost point of the nasal bones \\
3 & Intersection of the nasofrontal suture in the midline \\
4 & Intersection of the coronal and sagittal sutures \\
5 & Intersection of the sagittal and parietal-interparietal sutures \\
6 and 7 & Caudal end of the curvature of the occipital bone \\
8 and 9 & Rostralmost point of the rostral palatine fissure, left and right \\
10 & Caudalmost point of the palatine fissure, left and right \\
11 & Caudalmost point of the suture between palatine bones and the rostral border of the mesopterygoid fossa \\
12 and 13 & Rostralmost point of the foramen magnum \\
14 and 15 & Rostralmost point of the molar row, left and right \\
16 and 17 & Caudalmost point of the molar row, left and right \\
18 and 19 & Lateralmost point of the foramen magnum, left and right \\
20 and 21 & Rostralmost point of the zygomatic arch, left and right \\
\hline
\end{tabular}

(see Additional file 1, Table S1). On the other hand, our analyses were performed on the symmetric component of the shape variation as recommended by Savriama and Klingenberg [42]. We obtained shape variables of landmark's configuration by performing a Procrustes superimposition that eliminated differences due to translation, scaling and rotation [35]. Procrustes coordinates matrices and their covariance matrices were obtained and analyzed applying standard multivariate methods implemented in the software MorphoJ v.1.06d [35]. We assessed the shape variation of crania of both species by performing a PCA. In order to evaluate an eventual insular cranial size increase, we obtained the cranial centroid size of insular and mainland specimens. Centroid

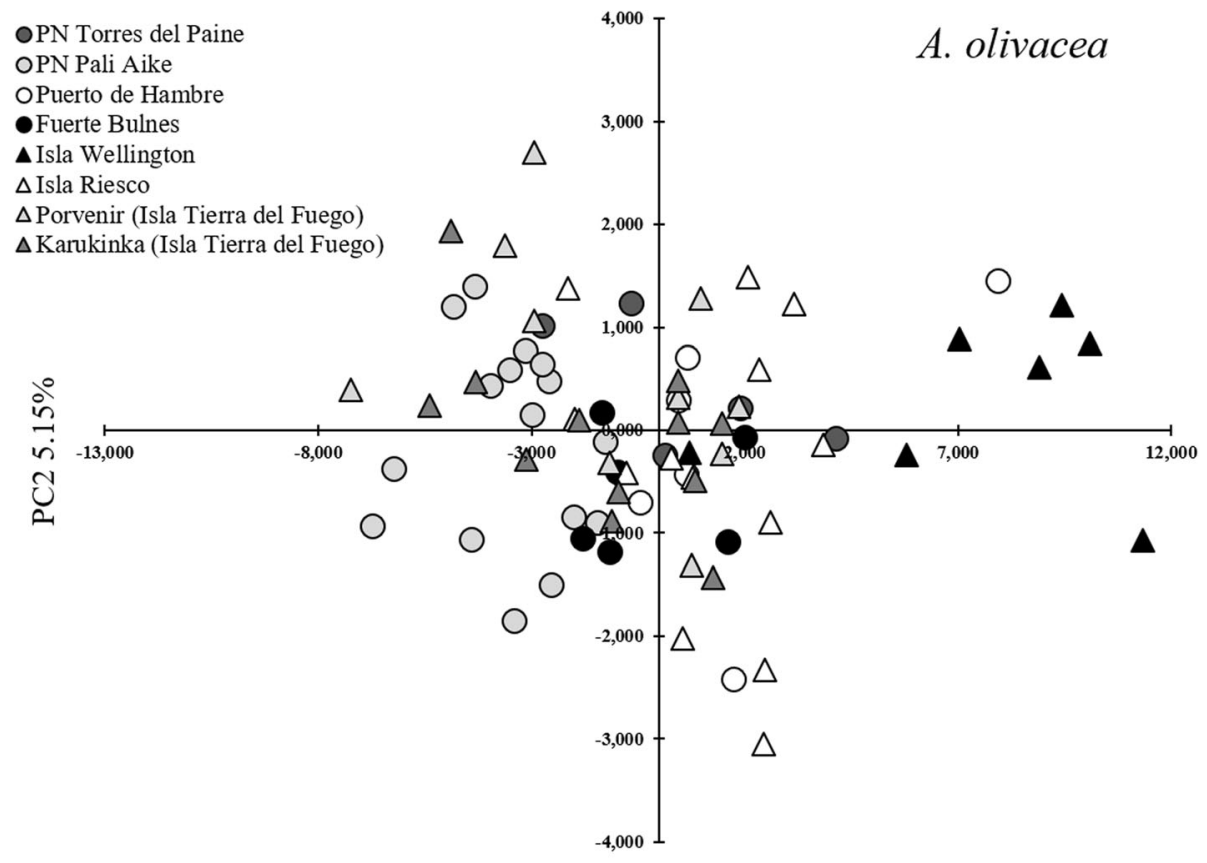

PC1 68.53\%

Fig. 3 Principal Component Analysis (PCA) of the linear morphometric approach for A. olivacea along Principal Component 1 and 2 (PC). PN = Parque Nacional, circles $=$ mainland localities, triangles $=$ insular localities 
size is calculated as the square root of the sum of squared distances of each landmark to the center of the configuration [43]. Later, a Procrustes ANOVA was performed to test the differences in the centroid size between insular and mainland individuals of each species in MorphoJ v.1.06d [35].

\section{Results}

\section{Linear morphometric analysis}

The PCA plot for A. olivacea is presented in Fig. 3. PC1 and PC2 explained the 68.53 and $5.15 \%$ of the total variance, respectively. Analysis of the PC1, that showed the largest proportion of variance, was associated to the morphological differences between insular and mainland specimens. Samples from mainland sites grouped mainly along the negative values of this component. However, insular individuals were more spread out throughout PC1 axis. The two populations from Tierra el Fuego island (Porvenir and Karukinka) were distributed along PC1 (negative and positive region) overlapping with mainland samples, whereas, samples from Isla Riesco and Isla Wellington were mostly present at the positive side of PC1 axis. Interestingly, samples from Isla
Wellington occupied the most extreme distribution along positive values of PC1. The logistic regression model indicated that cranial size is significantly associated with the probability of inhabiting island (Category 1) (Slope $=0.144, S E=0.067, G=5.254, P=0.0218$; Intercept $=0.253, \quad S E=0.23531 ; \quad$ Log-likelihood $=-51.618$ ). The probability of inhabiting an island increased with the increment of cranial size (Slope $=0.144$ ). Positive values of PC1 (i.e., bigger cranial size) were always associated to islands, with probabilities higher than 50\%.

The PCA plot for O. longicaudatus is shown in Fig. 4. PC1 and PC2 explained the 57.90 and $9.76 \%$ of the total variance, respectively. Compared to A. olivacea, samples of $O$. longicadatus did not show an evident pattern of morphological differentiation along the mayor axis of variation or PC1 (see boxplots of linear size variation in Appendix C, Additional file 1). A subtle separation was detected along PC2 (9.76\% explained variance), where samples from insular localities (mainly Isla Wellington, Parque Nacional Kawésqar and Isla Navarino) were displayed along positive values of PC2. The logistic regression model indicated that cranial size was not associated with the probability of inhabiting island (Category 1)

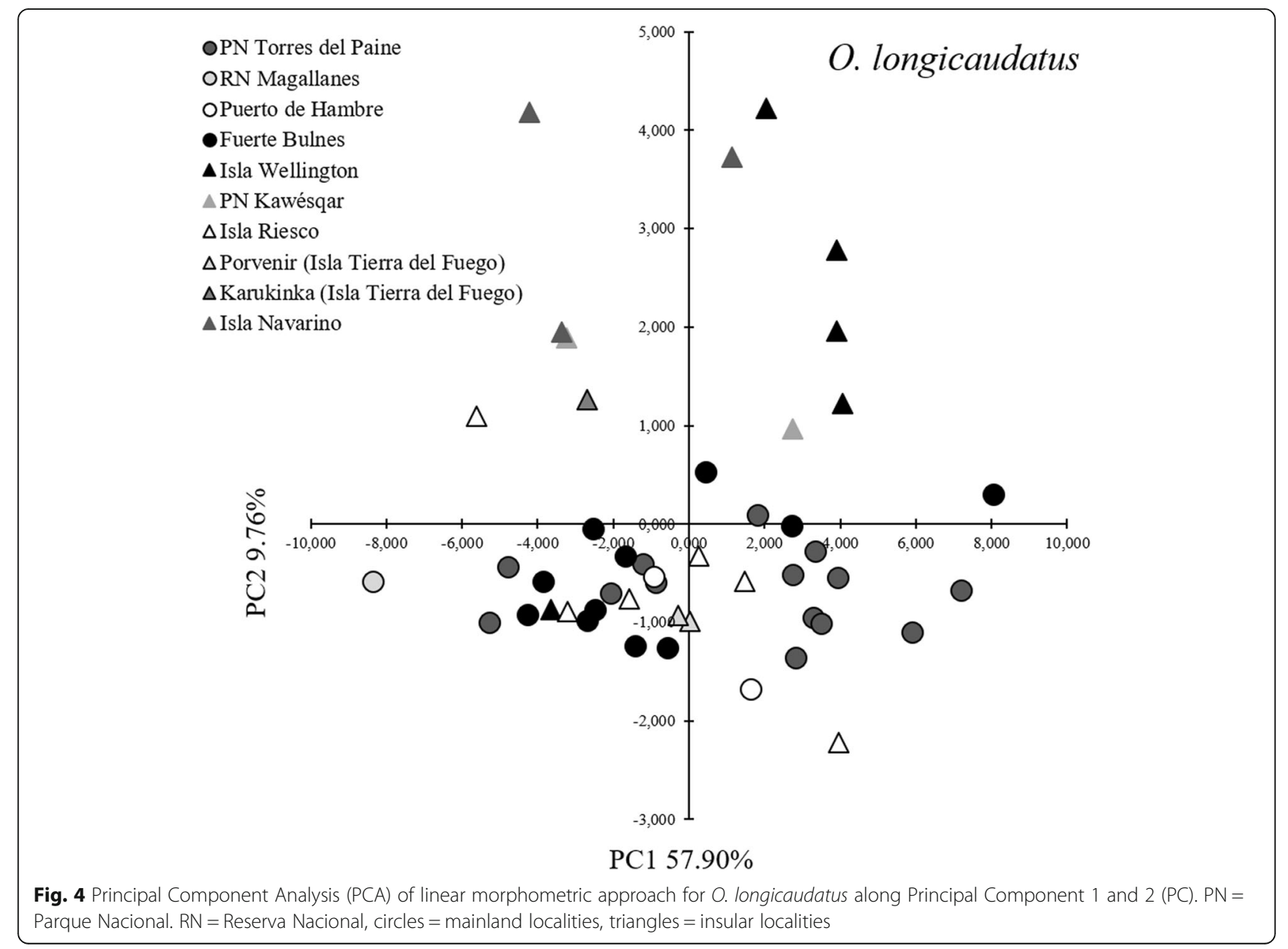


(Slope $=-0.036, S E=0.082, G=0.195, P=0.658$; Intercept $=-0.289, S E=0.289$; Log-likelihood $=-33.365$ ).

\section{Three-dimensional geometric morphometric analysis} After PCA was performed, a total of 31 Principal Components (PC) were obtained. PC1 and PC2 explained the 30.63 and $14.93 \%$ of the total variance, respectively. The remaining PCs represented low percentage of variance, therefore, they were not considered in the analysis. PC1 and PC2 are displayed in Fig. 5. With respect to the cranial shape variation, PCA showed that within each species, insular and mainland samples were highly overlapped along PCs. Thus, we did not observe any pattern of cranial shape variation along Fuegian archipelago. On the other hand, the results of size variation of the geometric morphometric and linear measurements were similar. Samples from Isla Wellington exhibited bigger cranial traits, as it can be observed at PC1 values distribution (Fig. 6). Specimens from Isla Riesco and Isla Capitán Aracena were also distributed along positive PC1 scores, but partially overlapped with mainland populations. This result was obtained with respect to the mainland specimens of A. olivacea that grouped to lower values of cranial size. In particular, samples from Isla Wellington were displayed along the most extreme range of the centroid size axis, indicating that these insular specimens presented the bigger size of crania compared to overall sampled localities for this species. Such differential distribution of Isla Wellington population described for $A$. olivacea, was not observed in $O$. longicaudatus. Indeed, insular and mainland samples for the latter species resulted highly overlapped along centroid size axis. In fact, statistical differences were obtained when we compared the cranial size of insular and mainland specimens for $A$. olivacea $($ d.f. $=1.71 ; F=7.51$; $P=0.0078$ ). However, for $O$. longicaudatus such differences were not significant $(d . f .=1.41 ; F=0.56 ; P=$ 0.4597). See comparative boxplots of centroid size variation in Appendix C, Additional file 1.

\section{Discussion}

As we former predicted, $A$. olivacea showed higher levels of morphological variation in comparison with $O$. longicaudatus, along the southern Patagonia of Chile. Moreover, such variation was associated to cranial size differences. Our morphometric analyses showed that in A. olivacea, individuals from Isla Wellington are of bigger cranial size if compared to their conspecifics of any other sampled locality along Patagonia. Additionally, we also observed a slight tendency to a bigger cranial size for specimens from Isla Riesco. In fact, the probability of inhabiting an island increased with higher values of cranial size in A. olivacea. Instead, the latter pattern was not observed in Oligoryzomys longicaudatus. Actually, this species did not exhibit significant differences in cranial size between insular and mainland individuals, although a very subtle variation of specimens from Wellington, Capitán Aracena and Navarino islands was observed. Thus, our data suggest that geographic isolation could be a relevant feature behind the cranial morphological differentiation of $A$. olivacea in the Fuegian archipelago. Moreover, such differences seem to vary according to classical evolutionary trends described for mammals (i.e., the Island Rule $[4,11]$ ). However, further

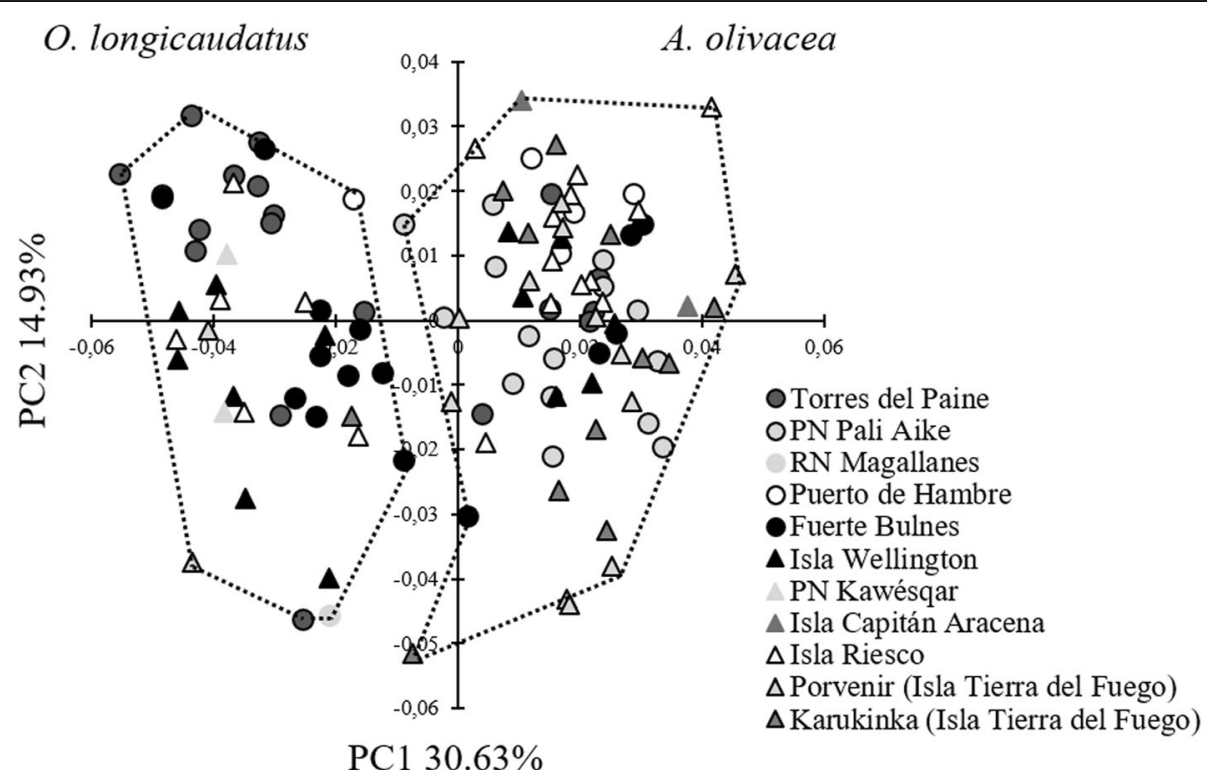

Fig. 5 Principal Component Analysis of the geometric morphometric approach along the Principal Components 1 and 2 (PC). Both species are displayed along the axes. PN = Parque Nacional, RN= Reserva Nacional, circles = mainland localities, triangles = insular localities 


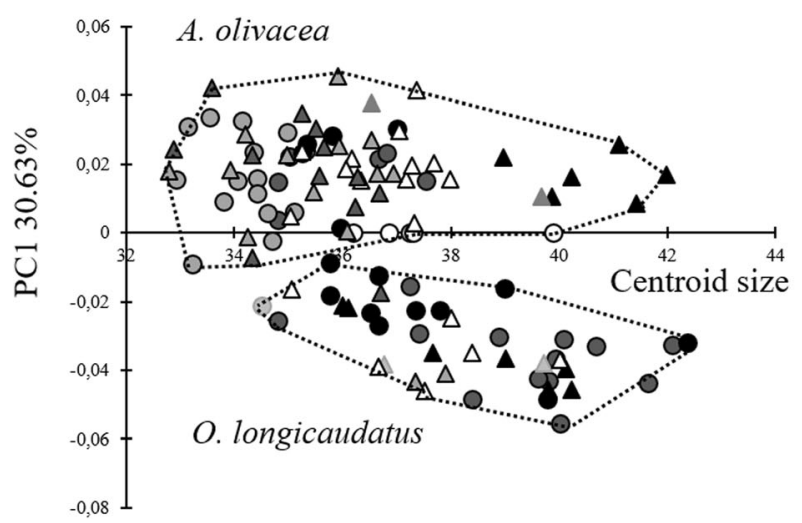

OTorres del Paine

OPN Pali Aike

RN Magallanes

OPuerto de Hambre

- Fuerte Bulnes

$\Delta$ Isla Wellington

$\triangle$ PN Kawésqar

$\triangle$ Isla Capitán Aracena

$\Delta$ Isla Riesco

$\Delta$ Porvenir (Isla Tierra del Fuego)

$\Delta$ Karukinka (Isla Tierra del Fuego)

$\mathrm{PN}=$ Parque Nacional, RN = Reserva Nacional, circles = mainland localities, triangles = insular localities

studies should be carried out to test exhaustively the prediction of the Island Rule in this sigmodontine rodent.

How can we explain the differences in the pattern of morphological variation for the two rodents studied in Patagonian localities? We suggest that a synergistic effect of the entangled geomorphologic scenario of Patagonia, the historical glacial processes that affected the region, and the idiosyncratic dispersal capability (vagility) of each species, might be among the major reasons. Successive events of connection and isolation between Tierra del Fuego island, the southern tip of continental South America, and several islands surrounding these land masses (e.g. Harrison and Navarino) were produced during Pleistocene period [21]. Product of ice sheets and sea level dropping (up to $100 \mathrm{~m}$ ), potential geographic scenarios for the passage or dispersal of biota through glacial bridges between mainland and islands could have occurred in the Magallanic region. Thus, small mammal populations may have been in geographic contact through insular and mainland territories in Patagonia, with low possibilities of local differentiation due to isolation, especially for $O$. longicaudatus due to its greater dispersal capacity compared to A. olivacea [24, 44].

On the other hand, Lomolino [4] exhibited a marked positive curvilinear correlation between area of the island and body size, and a negative correlation between body size and distance from the island (the longer the distance, the smaller the body size). In our results, we found a subtle increase in cranial size for specimens of A. olivacea from Isla Riesco, which is very close to the mainland, separated from the continent by narrow channels and sines (i.e., the Otway Sinus). Specimens from Tierra del Fuego island, however, did not show an evident pattern of cranial size differentiation with respect to the mainland. As Lomolino [45] suggested, body size of individuals inhabiting large islands, seems to vary as if they were at the continent. This would be the case for populations from Tierra del Fuego. In addition, the latter island is very close to the mainland. In fact, the narrowest portion between Tierra del Fuego and the mainland (Primera Angostura) is about $3.7 \mathrm{kms}$, and with a surface of $48,000 \mathrm{~km}^{2}$ represent the biggest island of the Fuegian archipelago. Meanwhile, the Wellington and Riesco islands, with their 5500 and $5000 \mathrm{~km}^{2}$ respectively, constitute the second and the third largest islands sampled in this study, being almost 10 times smaller than Tierra del Fuego. Hence, the geographic proximity of Tierra del Fuego to the mainland, as well as its large geographic extension, could resemble a small continental area. Therefore, we should not expect major differences in cranial size for the small mammals inhabiting this area. In fact, specimens from Tierra del Fuego resulted about the same size with respect to those of the continent in our study. Regarding Oligoryzomys from Navarino Island, we just found a subtle increase in cranial size. This island located below Tierra del Fuego, is separated from the latter through the Beagle Channel by less than $50 \mathrm{kms}$, and it constitutes the smallest island $\left(2473 \mathrm{~km}^{2}\right)$ sampled in this study. Furthermore, we just analyzed only three specimens of Oligoryzomys from Navarino, so probably we were not obtaining the real variation present on this island.

Our data supported the tendency of Abrothrix olivacea to increase its cranial size on islands. This fact was particularly recognizable for individuals from Isla Wellington. Some studies evaluating changes in size and morphology in different orders of insular mammals, have concluded that these evolve at a faster rate than their mainland congeners, and by a greater rate when they occur in smaller islands [46] (although see [47]). The latter scenario could explain the increment of cranial size in A. olivacea from Wellington island, since as it was mentioned above, that insular area is almost 10 times smaller than Tierra del Fuego. In addition, this phenomenon could be also related to the strong 
selection pressure faced for the island populations of $A$. olivacea in Wellington, due to the longer history of isolation across the last two glacial periods $(\sim 0.2$ Mya [23]). This is besides Isla Wellington is very close to the continent and surrounded by other islands. Furthermore, Isla Wellington is located next to the Southern Icefields (a remnant of the LGM), an area that was severely glaciated during the LGM of the Pleistocene. However, the presence of glacial refuges in Isla Wellington according to palynology and fossil record of insects, was later corroborated for Abrothrix olivacea and the deer Hippocamelus bisulcus [23, 48, 49]. On the other hand, no species of carnivores have been recorded on this island [50]). The only known predators of this system are some raptors occasionally sighted by local people (Park Rangers of Bernardo O'Higgins National Park, personal communication to ER-S). Thereby, the strong cranial size differentiation of $A$. olivacea (as noticed in our linear and geometric morphometric analyses) may have its origins in the absence of predators, and long periods of isolation to monopolize local resources. In fact, in the light of most recent molecular evidence, the geographic forms of A. olivacea from Isla Wellington, are recognized as the subspecies Abrothrix olivacea markhami [23], proposal that we would be supporting with our morphometric data.

The slight increase of cranial size that we observed in O. longicaudatus from Isla Wellington, agreed with previous studies that have shown a subtle mass increment for this mouse on Patagonian islands [51], but such small variation has not been associated with the occurrence of an insular race of $O$. longicaudatus. However, in the Harrison and Capitan Aracena islands of Patagonian fjords $\left(54^{\circ} \mathrm{S}\right)$ a new species of Oligoryzomys has been recently described, Oligoryzomys yatesi [27]) based on morphology, chromosomes and molecular sequence data. The relevant point here is that some male specimens of $O$. yatesi where about double the size if compared to its sister species $O$. longicaudatus from mainland Magallanes region. Two of us (REP \& ER-S) captured nine specimens from Harrison Island (the type locality for this new species), an island that is half the size of the smallest islands sampled in this study.

Interestingly, our morphological data did not recognize the occurrence of the other two subspecies of A. olivacea in Patagonia, A. o. canescens and A. o. xanthorhina, as it was proposed by Rodríguez-Serrano [52]. The first subspecies would be mostly restricted to the Brunswick Peninsula and mainland Magallanes: Torres del Paine, Magallanes National Reserve, Fuerte Bulnes and other nearby localities sampled in this study, whereas, A. o. xanthorhina would be restricted to islands such as Tierra del Fuego and Riesco [52]. Nevertheless, ongoing phylogeographic studies for Patagonian populations of $A$. olivacea are recovering two major clades in the area: one restricted to islands and the other for the mainland, which would correspond to both subspecies canescens and xanthorhina, respectively (unpublished data). These results agreed with the finding of two allopatric clades between Tierra del Fuego and Patagonian mainland populations evaluated with molecular data by Lessa et al. [26] and Abud [53]. The incongruence between morphological and molecular variation could be explained because the former usually responds to similar selective pressures along distributional gradients. This might not be reflecting the intrinsic genetic variation due to, for example, the biogeographical processes that affected the Patagonia ecoregion [54]. By contrast, Oligoryzomys longicaudatus that also characterizes for having a wide distributional range $\left(27-54^{\circ} \mathrm{S}\right)$, it does not show a strong structured population pattern along its geographic distribution, and in Patagonia a single subspecies is recognized, O. l. magellanicus [25]. Furthermore, underway phylogeographic studies in the area are not showing any structure for the latter taxon either in the mainland or the islands of Fuegian archipelago.

Overall, our study highlights that the morphological changes experienced by small rodent taxa in the Patagonia could be explained partially in terms of classical biogeographic trends (i.e., island size and distance or ecological pressure release, the Island Rule). However, factors such as the glacial history of Patagonia and the distinct dispersal abilities of A. olivacea and O. longicaudatus could be considered important subjacent causes. Therefore, it is possible that the higher levels of morphological variation observed in the crania of A. olivacea, compared to O. longicaudatus, could be a tendency of the former species to rapidly adapt to local conditions. Moreover, A. olivacea displays strong population structure by its lower vagility, scenario that could be reinforced under insular conditions (i.e., A. o markhami from Wellington island). We hope to stimulate future researches that extend our geographic sampling along mainland and islands of the Fuegian archipelago to test the findings of this study. In this line, our linear and 3Dgeometric morphometric data are valuable for a better comprehension of evolutionary tendencies of small mammals in the remote Patagonian region, in terms of the taxonomy of both species, and for eventual management programs.

\section{Conclusions}

The crania of $A$. olivacea showed higher levels of morphological variation compared to O. longicaudatus along the mainland and islands of the Fuegian archipelago. Morphological differences were observed in cranial size instead of shape. An increase of cranial size of insular forms was detected in A. olivacea, but not in $O$. 
longicaudatus. Moreover, our morphometric analyses consistently showed that for A. olivacea, individuals from Isla Wellington were of bigger cranial size than any other sampled locality of this species in Patagonia. We suggest that patterns of morphological variation observed in this study could be explained in term of historical biogeography, such as the glacial dynamic in Patagonia, and the differences in ecological features of the two studied species.

\section{Supplementary information}

Supplementary information accompanies this paper at https://doi.org/10. 1186/s40693-020-00094-9.

Additional file 1: Appendix A. List of the crania of $A$. olivacea and $O$. longicaudatus analyzed in this study. Appendix B. Test of Sexual Dimorphism in the crania of $A$. olivacea and $O$. longicaudatus by performing a Discriminant Function Analysis. Table S1. Result of the Procrustes ANOVA testing the error of digitization. Appendix C. Box plots of cranial linear and geometric size variation of $A$. olivacea and $O$. longicaudatus.

Additional file 2. Eigenvalues and Eigenvectors of Principal Component Analyses of linear morphometric data.

\section{Abbreviations}

LGM: Last Glacial Maximum; mtDNA: Mitochondrial DNA; ASM: American Society of Mammalogists; CDC: Center for Disease Control and Prevention; SSUC: Colección de Flora y Fauna Profesor Patricio Sánchez Reyes; SAG: Servicio Agrícola y Ganadero (Chile); CONAF: Corporación NACIONAL FORESTAL (Chile); PCA: Principal component analysis; PC: Principal component; ANOVA: Analysis of variance

\section{Acknowledgements}

We acknowledge the support of P. Zavala Curator of the Colección de Flora y Fauna Patricio Sánchez Reyes at Pontificia Universidad Católica de Chile and J. Reinoso for skull processing. We also thank the Curator of Mammals of the American Museum of Natural History (AMNH), Dr. Robert S. Voss from New York (USA), for allowing us to analyze and include specimens of Oligoryzomys longicaudatus and Abrothrix olivacea from that collection. Thanks to Corporación Nacional Forestal (CONAF, Chile) and Servicio Agrícola y Ganadero (SAG, Chile) for collecting permits.

\section{Authors' contributions}

The author (s) read and approved the final manuscript.

\section{Funding}

This study was supported by projects FONDECYT 1170761, 1170815 and 1170486.

\section{Availability of data and materials}

Data are available in the Additional file 1.

\section{Ethics approval and consent to participate}

This study was approved by the Bioethical Committee of the Pontifical Catholic University of Chile. All authors have given their consent to participate in this study.

\section{Consent for publication}

All authors have given their consent to participate in this study.

\section{Competing interests}

Not applicable.

\section{Author details}

'Laboratorio de Biología Evolutiva, Departamento de Ecología, Facultad de Ciencias Biológicas, Pontificia Universidad Católica de Chile, Av. Libertador
Bernardo O'Higgins 340, 6513677 Santiago, Chile. 'Laboratorio de Mastozoología, Departamento de Zoología, Facultad de Ciencias Naturales y Oceanográficas, Barrio Universitario s/n, Universidad de Concepción, Concepción, Casilla 160-C, 40703868 Concepción, Chile. ${ }^{3}$ Laboratorio de Ecología Evolutiva y Filoinformática, Departamento de Zoología, Facultad de Ciencias Naturales y Ocenográficas, Barrio Universitario s/n, Universidad de Concepción, Casilla 160-C, 40703868 Concepción, Chile. ${ }^{4}$ Universidad Católica de Santa María, Arequipa, Peru.

Received: 31 March 2020 Accepted: 9 July 2020

Published online: 14 July 2020

\section{References}

1. Darwin C. El origen de las especies. Madrid: Ed. SARPE; 1983.

2. Vidal MA, Veloso A, Méndez MA. Insular morphological divergence in the lizard Liolaemus pictus (Liolaemidae). Amphib-Reptil. 2006;27:103-11.

3. Dawson R, Milne N. Cranial size and shape variation in mainland and island populations of the quokka. J Zool. 2012;288(4):267-74.

4. Lomolino MV. Body size evolution in insular vertebrates: generality of the island rule. J Biogeogr. 2005:32(10):1683-99.

5. Runemark A, Brydegaard M, Svensson El. Does relaxed predation drive phenotypic divergence among insular populations? J Evol Biol. 2014;27(8): 1676-90.

6. van der Geer A, Lyras G, de Vos J, Dermitzakis M. Evolution of island mammals: adaptation and extinction of placental mammals on islands. Chichester, UK: Wiley-Blackwell; 2010.

7. Nuttall BM. The effects of isolation on endemic Cozumel Island rodents: a test of the island rule. Provo, Utah, United States of America: M.S. thesis, Brigham Young University; 2013.

8. Foster JB. The evolution of native land mammals of the queen Charlotte Islands and the problem of insularity. Vancouver, Canada: Dissertation, University of Columbia; 1963.

9. Foster JB. The evolution of mammals on islands. Nature 1964:202:234-5.

10. Van Valen L. Pattern and balance of nature. Evol Theory. 1973;1:31-49.

11. Lomolino MV. Body size of mammals on islands: the island rule reexamined. Am Nat. 1985;125(2):310-6

12. Heaney LR. Island area and body size of insular mammals: evidence from the tri-colored squirrel (Callosciurus prevosti) of Southeast Asia. Evolution. 1978:32(1):29-44.

13. McNab BK. Resource use and the survival of land and freshwater vertebrates on oceanic islands. Am Nat. 1994;144(4):643-60.

14. Brown JH, Lomolino MV. Biogeography. Sunderland, Massachusetts, United States of America: Sinauer Associates, Inc.; 1998.

15. Lomolino MV. Island biogeography, immigrant selection and body size of mammals on island. United States of America: Dissertation, State University of New York at Binghamton; 1983.

16. Lomolino MV. Mammalian island biogeography: effects of area, isolation and vagility. Oecologia. 1984;61(3):376-82.

17. Álvarez-Castañeda ST, Nájera-Cortazar LA. Do island populations differ in size and shape compared to mainland counterparts? J Mammal. 2020 101(2):373-85

18. Ledevin R, Chevret P, Ganem G, Britton-Davidian J, Hardouin EA, Chapuis JL, et al. Phylogeny and adaptation shape the teeth of insular mice. Proc R Soc B Biol Sci. 2016:283(1824):1-9.

19. Valladares-Gómez A, Celis-Diez JL, Palma RE, Manríquez GS. Cranial morphological variation of Dromiciops gliroides (Microbiotheria) along its geographical distribution in south-Central Chile: a three-dimensional analysis. Mamm Biol. 2017:87:107-17.

20. Coronato AMJ, Coronato F, Mazzoni E, Vázquez M. The physical geography of Patagonia and Tierra del Fuego. Dev Quat Sci. 2008;11:13-55.

21. Paskoff R. Geomorfología costera. In: Díaz-Naveas J, Frutos J, editors. Geología Marina de Chile. p. 76-83. Comité Oceanográfico Nacional de Chile - Pontificia Universidad Católica de Valparaíso - Servicio Nacional de Geología y Minería de Chile. 2010. 115 pp.

22. McCulloch RD, Sugden DE. Reply: climatic inferences from glacial and palaeoecological evidence at the last glacial termination, Southern South America. J Quat Sci. 2000;16(3):293-4.

23. Rodríguez-Serrano E, Hernández CE, Palma RE. A new record and an evaluation of the phylogenetic relationships of Abrothrix olivaceus markhami (Rodentia: Sigmodontinae). Mamm Biol. 2008;73(4):309-17. 
24. Belmar-Lucero S, Godoy P, Ferrés M, Vial P, Palma RE. Range expansion of Oligoryzomys longicaudatus (Rodentia, Sigmodontinae) in Patagonian Chile, and first record of hantavirus in the region. Rev Chil Hist Nat. 2009;82(2): 265-75.

25. Palma RE, Boric-Bargetto D, Torres-Pérez F, Hernández CE, Yates TL. Glaciation effects on the phylogeographic structure of Oligoryzomys longicaudatus (rodentia: Sigmodontinae) in the southern Andes. PLoS One. 2012;7:1-12

26. Lessa EP, D'Ella G, PardiÑas UFJ. Genetic footprints of late Quaternary climate change in the diversity of Patagonian-Fueguian rodents. Mol Ecol. 2010;19(15):3031-7.

27. Palma RE, Rodríguez-Serrano E. Systematics of Oligoryzomys (Rodentia, Cricetidae, Sigmodontinae) from southern Chilean Patagonia, with the description of a new species. J Zool Syst Evol Res. 2018;56(2):280-99.

28. Murúa R, Gonzalez LA, Meserve PL. Population ecology of Oryzomys longicaudatus philippii (Rodentia: Cricetidae) in southern Chile. J Anim Ecol. 1986;55(1):281-93.

29. Zepeda PS, Rodríguez-Serrano E, Torres-Pérez F, Celis-Diez JL, Palma RE. Genetic variability and structure of the olive field mouse: a sigmodontine rodent in a biodiversity hotspot of southern Chile. PeerJ. 2019;7:e6955.

30. González LA, Murúa R, Feito R. Densidad poblacional y patrones de actividad espacial en Akodon olivaceus (Rodentia: Cricetidae) en hábitats diferentes. In: Salinas PJ editor. Zoología Neotropical, vol 2. Mérida, Venezuela: Actas VIII Congreso Latinoamericano de Zoología. 1982. p. 935-47.

31. van der Geer AAE. Changing invaders: trends of gigantism in insular introduced rats. Environ Conserv. 2018:45(3):203-11.

32. Martínez JJ, Sandoval ML, Carrizo LV. Taxonomic status of large- and middle-sized Calomys (Cricetidae: Sigmodontinae) from the southern Central Andes inferred through geometric morphometrics of the skull. J Mammal. 2016;97(6):1589-601.

33. Sikes RS. 2016 guidelines of the American Society of Mammalogists for the use of wild mammals in research and education. J Mammal. 2016;97(3):663-88.

34. Mills JN, Yates TL, Childs JE, Parmenter RR, Ksiazek TG, Rollin PE, Peters CJ. Guidelines for working with rodents potentially infected with hantavirus. J Mammal. 1995;76(3):716-22.

35. Klingenberg CP. MorphoJ: an integrated software package for geometric morphometrics. Mol Ecol Resour. 2011;11(2):353-7.

36. Gallardo MH, Palma E. Systematics of Oryzomys longicaudatus (Rodentia: Muridae) in Chile. J Mammal. 1990;71(3):333-42.

37. Breno M, Leirs $\mathrm{H}$, Van Dongen S. Traditional and geometric morphometrics for studying skull morphology during growth in Mastomys natalensis (Rodentia: Muridae). J Mammal. 2011;92(2):1395-406.

38. Hammer $\varnothing$, Harper DAT, Ryan PD. Past: paleontological statistics software package for education and data analysis. Palaeontol Electronica. 2001;4(1):1-9.

39. Zelditch ML, Swiderski DL, Sheets HD, Fink WL. Geometric morphometrics for biologists: a primer. San Diego: Elsevier Academic Press; 2004.

40. Whiley DF. Software. Landmark v. 3.0.0.6. Institute for Data Analysis and Visualization IDAV, Davis, United States of America; 2002-2005.

41. Klingenberg CP, Barluenga M, Meyer A. Shape analysis of symmetric structures: quantifying variation among individuals and asymmetry. Evolution. 2002:56(10):1909-20.

42. Savriama Y, Klingenberg C. Beyond bilateral symmetry: geometric morphometric methods for any type of symmetry. BMC Evol Biol. 2011;11: 280 .

43. Bookstein FL. Morphometric tools for landmark data: geometry and biology. Cambridge, U.K: Cambridge University Press; 1991.

44. Murúa R, González L. Regulation in numbers in two neotropical rodent species in southern Chile. Rev Chil Hist Nat. 1986;59(2):193-200.

45. Lomolino MV, Riddle BR, Whittaker JR. Biogeography: biological diversity across space and time. Sunderland, Massachusetts, United States of America: Sinauer Associates, Inc.; 2017.

46. Millien V. Mammals evolve faster on smaller islands. Evolution. 1935-1944; 2011:65-7.

47. Raia P, Meiri S. The tempo and mode of evolution: body sizes of island mammals. Evolution. 1927-1934;2011:65-7.

48. Ashworth AC, Markgraf V, Villagran C. Late Quaternary climatic history of the Chilean channels based on fossil pollen and beetle analyses, with an analysis of the modern vegetation and pollen rain. J Quat Sci. 1991;6(4): 279-91

49. Marín JC, Varas V, Vila AR, López R, Orozco-terWengel P, Corti P. Refugia in Patagonian fjords and the eastern Andes during the last glacial maximum revealed by huemul (Hippocamelus bisulcus) phylogeographical patterns and genetic diversity. J Biogeogr. 2013;40(12):2285-98.

50. Iriarte A, Jaksic F. Los carnívoros de Chile. Santiago, Chile: Ediciones Flora \& Fauna; 2017.

51. Guzmán JA, Carlos J, Cañón C. Variación morfológica de Oligoryzomys longicaudatus magellanicus (Rodentia: Sigmodontinae) al oeste de los Campos de Hielo Patagónico Sur en Chile. Mastozool Neotrop. 2015;22(2): 375-84.

52. Rodríguez-Serrano E. Consecuencias de las glaciaciones pleistocénicas sobre la diversidad genética de Abrothrix olivaceus (Waterhouse) (Rodentia: Cricetidae: Sigmodontinae). Santiago, Chile: Dissertation, Pontificia Universidad Católica de Chile; 2011

53. Abud C. Variación genética y estructura filogeográfica de Abrothrix olivaceus en la Patagonia argentina y el sur chileno. Ms thesis: Facultad de Ciencias, Universidad de la República, Montevideo, Uruguay; 2011.

54. Endler JA. Geographic variation, speciation and clines. Princeton, New Jersey: Princeton University Press; 1977.

\section{Publisher's Note}

Springer Nature remains neutral with regard to jurisdictional claims in published maps and institutional affiliations.

\section{Ready to submit your research? Choose BMC and benefit from:}

- fast, convenient online submission

- thorough peer review by experienced researchers in your field

- rapid publication on acceptance

- support for research data, including large and complex data types

- gold Open Access which fosters wider collaboration and increased citations

- maximum visibility for your research: over $100 \mathrm{M}$ website views per year

At $\mathrm{BMC}$, research is always in progress.

Learn more biomedcentral.com/submissions 